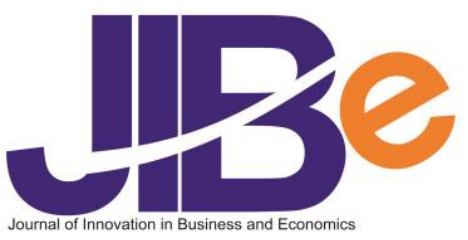

\title{
Factor affecting user satisfaction in agricultural e-commerce applications: Facing the new normal \\ Alfa Nursyamiza Nusifera ${ }^{1}$, Mukhamad Najib ${ }^{2}$, Kirbrandoko ${ }^{3}$
}

\author{
School of Business, IPB University, Jl. Raya Padjajaran, \\ Bogor 16151, Indonesia ${ }^{1}$ \\ Department of Management, IPB University, Indonesia, \\ Universitas Ibn Khaldun Bogor, Indonesia ${ }^{3}$
}

\begin{abstract}
Agricultural E-Commerce with a retail business model has a big challenge to become an alternative sales distribution of agricultural products. Consumer satisfaction and loyalty can be a strategy for companies to maintain and increase sales. The purpose of this study was to analyze the users of agricultural e-commerce application characteristics and variables that affect customer satisfaction and loyalty. It was conducted by a survey in the Greater Jakarta area, Indonesia. Research data were collected using a questionnaire with a convenience sampling method to 170 respondents. The majorities of respondents were women with an age range of 20-30 years. Structural Equation Modeling (SEM) results show that there is a significant influence between information quality, design, response, security, delivery on satisfaction, and satisfaction with loyalty. On the other hand, there is no significant difference between ability, payment, user service, and satisfaction. Companies can create loyalty programs to increase product purchase retention in agricultural e-commerce.
\end{abstract}

Keywords: Agricultural e-commerce; satisfaction; loyalty

\section{Introduction}

Online business on e-commerce platforms in Indonesia grows and gets more significant sales every year. In 2018, total e-commerce's total turnover reached 100 billion IDR per month and predicted will be increased continuously. Agricultural e-commerce is another form of a business model similar to ecommerce but focuses on agricultural products. The development of agricultural e-commerce in Indonesia has reasonably good progress. It can see from the emergence of many agricultural e-commerce startups. Currently, there are several e-commerce companies' names in the agricultural sector, such as Sayurbox, iGrow, Limakilo, TaniHub, Sikumis, Pasar Laut, Inagriasia, Kecipir, and many other e-commerce companies. Every e-commerce startup has a different business model and focus. The retail business model focuses on meeting the community's needs related to agricultural products such as vegetables, fruit, and meat (Katadata, 2018).

According to Das et al. (2016), Indonesia has successfully utilized digitalization to realize total productivity in all major sectors. The existence of e-commerce business development predictably will impact the increasing GDP reach USD 120 billion by 2025. However, the development of products and sales of the agricultural sector has no movement. It shows that agricultural e-commerce players must have a good marketing strategy to increase company sales. Data from Deloitte (2017), the percentage of online food product purchases still has a low rate, which is less than 5 percent. Indonesian people make more purchases online in the categories of clothing, electronics, tickets, and books. Consumers still choose to come to the store to buy groceries that they want to buy. Besides, problems that often occur in agricultural e-commerce are crashed in applications, failure of product purchase transactions, and product delivery processes that still experience many obstacles such as delays in shipping and product damage. It makes the company must continue to innovate to increase agricultural e-commerce user satisfaction.

The occurrence of the Covid-19 pandemic in 2020 in Indonesia makes consumer purchasing behavior likely to change. Social distancing requires everyone to work, study, and do all other activities at home. At the same time, demand for food products on various e-commerce platforms experienced a

\footnotetext{
1alfa.nusifera@gmail.com

2mnajib23@yahoo.com

${ }^{3}$ koko_kir@yahoo.com
} 
significant increase. This moment is the right time for agricultural e-commerce companies to gain the trust of customers. Permani (2020) explains that the government's decision on large-scale social restrictions increasingly limited people's mobility. When the beginning of the Covid-19 pandemic took place, consumers began to visit the e-commerce platform to buy food ingredients until the number of consumer basket sizes increased. It shows the role of e-commerce in providing food for the community. Producers of fresh food, such as fruit and vegetable growers, meat processors, and poultry, began to show a high interest in joining selling on the e-commerce platform. The Ministry of Agriculture also formed a partnership with the e-commerce platform to distribute subsidized rice. Agricultural e-commerce application companies must utilize this momentum to gain customers and increase the number of transactions from registered customers, increasing customer satisfaction and loyalty.

According to Semejin et al. (2005), loyal consumers have an essential role in the survival of a business. Tsoukatos and Rand (2006) state that companies can use marketing strategies to increase market share and profits by maximizing repeat purchases from customers. Liu et al. (2008) develop a satisfaction evaluation model by emphasizing China's entire e-commerce environment through three important parts to evaluate performance, namely: a) information retrieval and evaluation of alternatives (information quality, design, merchandise attributes); b) purchases (transaction capabilities, response, security and privacy, payments); and c) post-purchase (delivery, customer service). This concept is a development from Kotler (2010) related to the purchasing decision process framework.

The study replicated the research model Liu et al. (2008) conducted to determine e-commerce users' consumer satisfaction in China. The author uses a research model to assess the satisfaction of agricultural e-commerce respondents in Indonesia. In this study, a model was developed by adding consumer loyalty variables to obtain broader managerial implications. The objectives of the research include: 1) identifying the characteristics of respondents of agricultural e-commerce application users; 2) analyzing the influence of information quality, design, capability, response, security, payment, delivery, and customer service affects the satisfaction and loyalty of agricultural e-commerce customers; 3 ) assessing appropriate managerial implications for increasing satisfaction from agricultural e-commerce customers?

\section{Literature Review}

Previous research were conducted to have a better understanding of the theoretical basis, stages, and research methods associated with customer satisfaction with online purchases. Rangkuti (2011) defines that consumer satisfaction as a response of the suitability between the level of importance possessed by consumers and the actual performance felt by consumers after using or using them. The study replicated the research model by Liu et al. (2008) to determine the consumer satisfaction of e-commerce users in China. The author uses a research model to assess the satisfaction of agricultural e-commerce respondents in Indonesia. This study examines the hypotheses made based on the background and research problems.

\section{H1: The quality of information affects satisfaction}

The quality of information is an important variable that must be fulfilled by online stores because it makes consumers easier when they search for information. The quality of Information affects costumers' satisfaction. Hidayati and Harimurti (2017) state that the effect of the quality of Information on the use of e-filling has a significant and positive effect on user's satisfaction. This condition is caused by accurate and complete information. According to Chen and Wu (2017), in order for consumers to be interested in buying. The store must present a photo of the food, otherwise consumers will never order food at the store. Consumers will be interested in making purchases based on recommendations from friends, previous buyers, photos, and reviews from previous consumers.

\section{H2: Design affects satisfaction}

Rasli et al. (2018) explain that design, quality of Information, security, ease of payment and delivery processes have an influence on consumers' satisfaction of e-commerce users. Based on Chen et al. (2012), user-friendly design is an important factor that ensures success for a site in increasing its usage and its satisfaction. Dharmesti and Nugroho (2012) explain that good design is related to neat screen appearance, loading paths and the right color combination so that consumers feel comfortable and satisfied.

H3: Capability affects satisfaction 
The capability referred to the research is the application's ability to respond customers when making transactions in the application. Teviana et al. (2017) provide an explanation that capabilities in marketing have a significant effect on customer satisfaction. This is due to the ability to provide value related to advantages to its consumers. Kim and Stoel (2004) tested the capability of the website using two indicators, which are technical and managerial.

\section{H4: Response affects satisfaction}

Mardatilla et al. (2017) explain that response has a significant effect on satisfaction. This is related to the ability to serve consumers in response or reactions to the actions taken. The response in the study is defined as the respondent's response to service capabilities. According to Soemanto (1998), response can be seen from information processing and technology abilities.

\section{H5: Security affects satisfaction}

Security is important in e-commerce activities. Security will gain confidence in form of satisfaction from its customers. According to Fatikasari (2018), security is an important thing that can affect user satisfaction. This is because it involves personal information in it.

H6: Payment affects satisfaction

Another factor that affects e-commerce user satisfaction is payment. Alwafi and Magnadi (2016) provide an explanation that ease of payment has a significant effect on satisfaction in using e-commerce services. This is because users want their activities to be safer, more practical, and well-coordinated.

\section{H7: Delivery affects satisfaction}

According to Liu et al. (2008), delivery and also customer service play a critical role in Chinese customer satisfaction. Delivery has the greatest impact on satisfaction than the other variables. The results of Rachman and Safri's research (2018) show that delivery is important for companies in order to distribute products quickly and safely according to orders purchased by consumers. This needs to be maintained because of its significant impact on satisfaction.

\section{H8: Customer service affects satisfaction}

Mohammad et al. (2015) explain that service has a strong influence on the satisfaction of ecommerce consumers which is often associated with the ability to respond to each request from its customers. E-commerce consumer satisfaction is also influenced by the process of sending the ordered product which consumers expect certainty from the time and safety of the products they order (Mahmood 2016). Chen and $\mathrm{Wu}$ (2017) state that consumers are interested in making online purchases at stores that claim to deliver food within 30 minutes. Gajic and Booklaky (2015) explain that good service can have a positive and significant impact on satisfaction. This condition is caused by the expectation of consumers to continue to be noticed by the company when the transaction is made.

\section{H9: Satisfaction affects loyalty}

Bhaskar and Kumar (2015) explain that satisfaction is an important thing that can affect the loyalty of consumers, due to the expectations that have been fulfilled by a product. According to Musfar and Vivi (2012), loyalty from consumers is very important in the drive to continue to create sales. According to Tjiptono (2000), there are several indicators that can be used to measure consumer loyalty, which are making repeat purchases and recommending brands to others. Loyal consumers will tend to make repeat purchases of a product or service that they consider capable of satisfying themselves. Loyal consumers will automatically convey and recommend to others to share the products or services used by them. 


\section{Research Method}

The research conducted in March 2019 to June 2020 was attended online to users of agricultural e-commerce applications in the Greater Jakarta area. The Jabodetabek area was chosen as the regional representative of major cities in Indonesia. Quantitative assessments used to study the factors that influence respondent satisfaction of agricultural e-commerce users. The type of data used in this study consisted of primary data. Primary data obtained from an online survey result from customers who have purchased on the agricultural e-commerce platform. The technique of determining the sample in this study to answer all problems in the research carried out with convenience sampling. Respondents are people who have used agricultural e-commerce applications. The questionnaire instrument was structured to make it easier for consumers to understand the contents of the questionnaire. The questionnaire contained closed questions to make it easier for respondents to choose several alternative answer choices provided by researchers. The scale used is a Likert scale.

Table 1. Operational Variables

\begin{tabular}{|c|c|c|}
\hline Variables & Definition & Dimensions \\
\hline $\begin{array}{l}\text { Loyalty } \\
\text { (Tjiptono, 2000) }\end{array}$ & $\begin{array}{l}\text { Customer commitment to service with a positive response to long- } \\
\text { term purchases }\end{array}$ & $\begin{array}{l}\text { Repeat order } \\
\text { recommendation }\end{array}$ \\
\hline \multirow{4}{*}{$\begin{array}{l}\text { Satisfaction } \\
\text { (Kotler \& Keller, } \\
\text { 2009) }\end{array}$} & \multirow[t]{4}{*}{ Customer evaluation of services to meet needs and desires. } & Loyal \\
\hline & & Repurchase \\
\hline & & $\begin{array}{l}\text { Talk about good } \\
\text { things. }\end{array}$ \\
\hline & & Offering ideas \\
\hline \multirow{4}{*}{$\begin{array}{l}\text { Information } \\
\text { quality } \\
\text { (Andarwati \& } \\
\text { Sankarto 2008) }\end{array}$} & \multirow{4}{*}{$\begin{array}{l}\text { Meet the information needs and accuracy of delivery to balance } \\
\text { customer expectations. }\end{array}$} & Accurate Information \\
\hline & & $\begin{array}{l}\text { Understandable } \\
\text { information }\end{array}$ \\
\hline & & Complete information \\
\hline & & Relevant Information \\
\hline \multirow{3}{*}{$\begin{array}{l}\text { Design (Liu et } \\
\text { al. 2008) }\end{array}$} & \multirow[t]{3}{*}{ Fullfilment the needs of displaying content on online store pages. } & Design structure \\
\hline & & Navigation \\
\hline & & Color \\
\hline \multirow{2}{*}{$\begin{array}{l}\text { Capability } \\
\text { (Kim and Stoel, } \\
\text { 2004) }\end{array}$} & \multirow[t]{2}{*}{ Evaluate service capabilities. } & Technique \\
\hline & & Managerial \\
\hline \multirow{2}{*}{$\begin{array}{l}\text { Response } \\
\text { (Shanka et al. } \\
\text { 2003) }\end{array}$} & \multirow[t]{2}{*}{ Respondent responses in capabilities services. } & Information processing \\
\hline & & Technology ability \\
\hline \multirow{2}{*}{$\begin{array}{l}\text { Security } \\
\text { (Szymanski \& } \\
\text { Hise 2000) }\end{array}$} & \multirow{2}{*}{$\begin{array}{l}\text { Customers want to be convinced to trust a technology related to } \\
\text { information and all ownership. }\end{array}$} & Security features \\
\hline & & Confidence \\
\hline \multirow{4}{*}{$\begin{array}{l}\text { Payment } \\
\text { (Humphrey, } \\
\text { 2001) }\end{array}$} & \multirow[t]{3}{*}{ Customer preferred payment method. } & Credit card \\
\hline & & Digital wallet \\
\hline & & Cash \\
\hline & & Punctuality \\
\hline
\end{tabular}

Sampling has done by using the rule of thumb of the Structural Equation Model (SEM). Hair et al. (2010) state the number of samples needed is 5-10 times the number of research indicators. The number of indicator variables that make up the SEM model in the study amounted to 26. The data obtained from the survey results were 170 respondents. The sampling technique was a convenience sampling method. The variables used in this study are loyalty $(\mathrm{L})$, satisfaction $(\mathrm{K})$, quality of information (KI), design (D), capability (KA), response (R), security (KE), payment (P), shipping (DEL), and payment (PA). The indicators for each variable used showed in Table 1. Each indicator will be used as a reference to make questions in the research questionnaire. Data and information obtained were analyzed quantitatively. The 
study uses two data explains, namely, descriptive analysis and Structural Equation Model (SEM) analysis. The descriptive analysis aimed to study the characteristics of respondents and the shopping patterns of respondents. Analysis of the relationship of factors that influence consumer satisfaction of agricultural ecommerce users has been evaluated by using Structural Equation Model (SEM) analysis.

\section{Result and Discussion}

Overview of Agricultural E-commerce in Indonesia

In this globalization era, the business world rapidly grows. It is indicated by the growth of the retail industry sector, including e-commerce. Online selling and purchasing are the core business of ecommerce. E-commerce is also widely grown and demanded by business actors engaged in the agricultural sector. Currently, some e-commerce companies in the agricultural industry began to emerge, such as iGrow, Limakilo, TaniHub, Sikumis, Pasar Laut, Inagriasia, Kecipir, and many more.

Today e-commerce technology is essential and required to develop. It intended to keep pace with current development and streamline the supply chain of agricultural products so that communities can access quickly, and farmers have certainty of the sale. E-commerce functions change the agricultural supply chain as cited by Yashinta (2017), who identified the differences in the supply chain before and after the ecommerce application in a company presented in Figure 1.

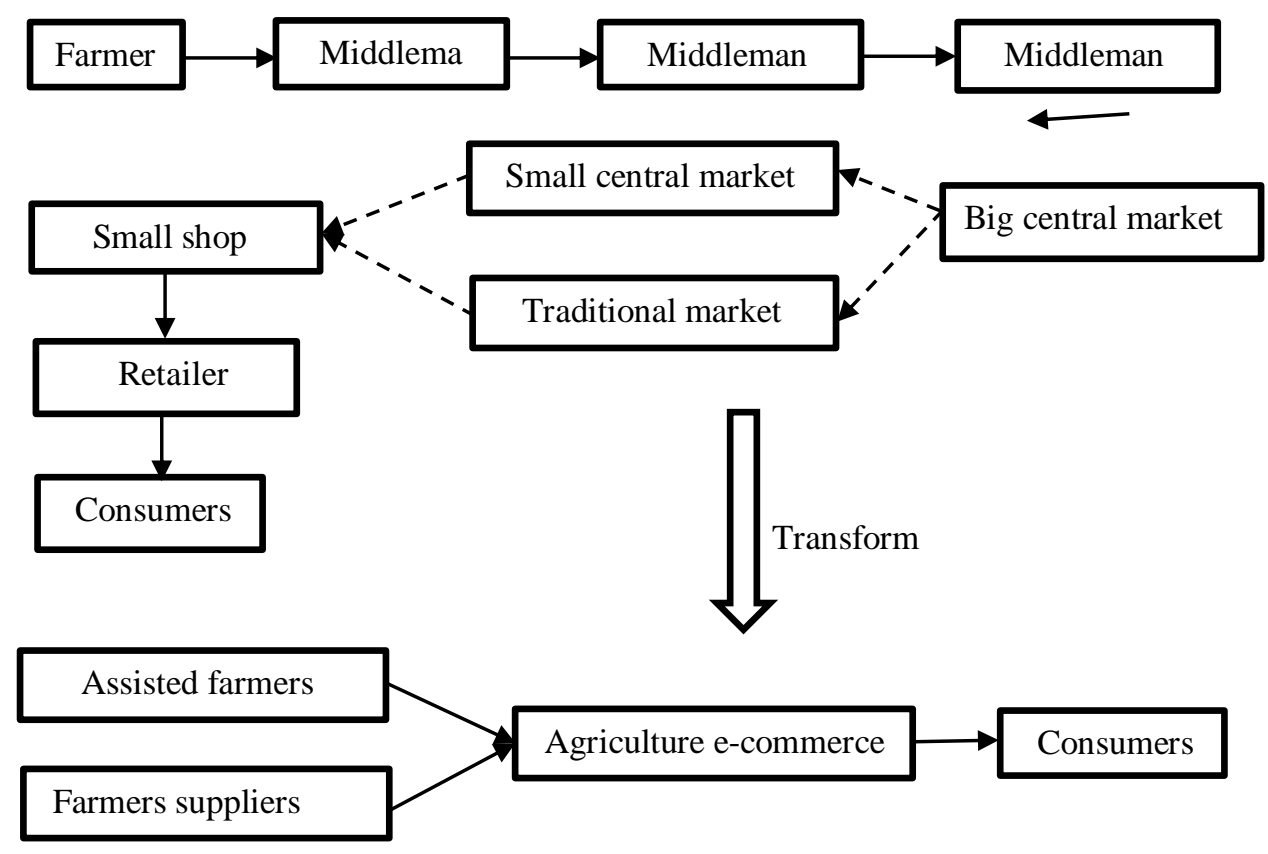

Figure 1. Changes in agricultural supply chain with e-commerce

The information in Figure 1 explains that e-commerce provides a significant benefit that is cutting large chains. Cutting this chain is expected to improve the standard of living of farmers who have the smallest profits compared to other sellers. Farmers are producers of agricultural products. Although the presence of e-commerce makes a lot of jobs disappear, e-commerce itself provides many benefits for business and economic growth in a country. In addition, eCommers also makes consumers easier to get good quality agricultural products at competitive prices.

According to Khan (2016), information technology has played a vital role in the future development of financial sectors and the way of doing business in an emerging economy like Bangladesh. Increased use of smart mobile services and the internet as a new distribution channel for business transactions and international trading requires more attention towards e-commerce security to reduce fraudulent activities. E-commerce has many benefits that add value to customer satisfaction in terms of customer convenience and enables the company to gain a more competitive advantage over the other competitors. Oresanya and Oresanya (2016) state that e-commerce had become one of the particular ways of shopping because of its easiness and convenience. Customers can access details and descriptions of products or services they intend to buy from the online catalog and after that purchase at any point in time. 
All transactions can be done at their home. In addition, e-commerce provides buying options that are quick, convenient, and user-friendly with the ability to transfer funds online, helping customers save time. It has been a catalyst to accelerate economic growth in many developed countries around the world.

\section{Characteristics of Respondents}

The data resulted through interviews using questionnaires with 200 respondents and showed only 170 respondents' data that met the requirements. The results indicate the sexes of respondents was essential and able to describe the role in deciding consumption activities that bring impacts on customer satisfaction and loyalty. The majority of respondents sampled in the study were female. Women are still considered the main actors in the shopping activities of daily products (vegetables, fruits, and other home-based needs) but in a different way using technology, namely agricultural e-commerce.

The ages of respondents describe the generations of application users. Description of the generation becomes essential in making future marketing approaches related to e-commerce applications. Kusuma and Prasetya (2017) explain that there are different approaches used by developers in marketing technology-based products. The majority of respondents who used e-commerce applications were 20-30 years old. This condition indicates that the respondents are the final generation $\mathrm{Y}$ who have been closely exposed by technology. Generation $\mathrm{Y}$ is a group that plays a crucial role in the use of technology, especially agricultural e-commerce.

Marital status is an important part that can provide a role in the activities of the use of agricultural e-commerce conditions caused by obligations in life. Manoppo and Abdurachman (2009) explain that there are differences in marital status in marketing patterns. E-commerce users who are respondents in the majority of research are married. This condition is in line with the style of users who want to be more practical with responsibilities.

Education is important to illustrate the level of knowledge on the development of science. In this study, it is technology. The majority of respondents held a bachelor's degree in which this finding indicates that they are individuals who have advanced education levels. It is used as a basis for offering products to users by using smarter approaches. Jobs describe the daily activities and sources of income they have. The developers use job information as a basis in the focus of offering to increase the number of users. The majority were employees or workers, but most of them were working for private companies. The findings indicate that users have income and daily routine activities.

Respondents' incomes describe the potential for application developers related to the amount spent by users. Information about income is also used as a map of the product segmentation offered. The majority of respondents' incomes were above 10 million rupiah with the most composition at IDR 10,000,000 $15,000,000$. This finding indicates that the users of agricultural e-commerce applications classify in the upper-middle class. Developers can offer products with medium grade to the market on the apps. Most of the respondents' expenses to meet their families' needs were IDR 6,000,000 - 8,000,000. It is the amount that can be contested by agricultural e-commerce developers every month.

\section{Respondents' Purchasing Behavior in Agricultural E-commerce}

Shopping behavior that occurs in e-commerce users as research samples can be illustrated by various things such as applications, products purchased, number of transactions, length of use, and other identification. Most of the transaction values each time using the agricultural e-commerce application were IDR 100,000 - 200,000. The majority of users of e-commerce applications were new users; thus, their usage activities are maintained so that they keep using the app. Shopping behavior is a process of searching, selecting, purchasing, using, and evaluating to meet daily needs. Information on shopping behavior used to describe how e-commerce applications users use applications to fulfill their needs.

Deloitte (2014) conducted a survey of 2000 consumers in the United Kingdom. The results show people closest to you (family and friends) and reviews from previous buyers. They scored sixty percent as trustworthy sources of information when searching for products in online stores. Farag and Lyons (2007) found that online searches and perceptions of benefits positively influence online purchases. Kim and Park (2005) state that consumers tend to look for more information from the internet when buying products online. It shows, companies must focus on improving good reviews from customers so that potential customers get good information. Hence, they are interested in purchasing agricultural products in agricultural applications.

After consumers buy products, Millennials consumers will carry out activities to share the information they own. Share activity is an essential part of digital marketing today, where this is a free promotion media related to the assessment of respondents on the products used. The majority of respondents shared their use activities and products purchased from agricultural e-commerce based on the results of the 
study. Consumers who are satisfied or dissatisfied with the product purchased will usually share and provide a review of the product. This process determines whether the company will get good or bad reviews about the product sold. Besides, companies can also use several marketing strategies such as giving a giveaway, product bundling, endorsement, and other strategies to increase the 'sharing' activity of customers.

According to Floh et al. (2013), online consumer reviews about products or services significantly influence consumer attitudes or behaviors towards purchasing decisions. According to Lackermair et al. (2013), reviews and product ratings are top-rated tools to support consumer purchasing decisions. Ratings and reviews are precious for online retailers who use ranking systems to build trust and reputation in the online market. The results showed that as many as 74 percents of 104 respondents agreed and strongly agreed that online product reviews were an important factor in making a purchase.

\section{Structural Equation Modeling Analysis for Agricultural E-commerce}

Structural Equation Modeling analysis is a method used to determine the correlation among variables and indicator variables with variables. This method consists of several stages to determine the best possible results. The description of the study model shown in Figure 2.

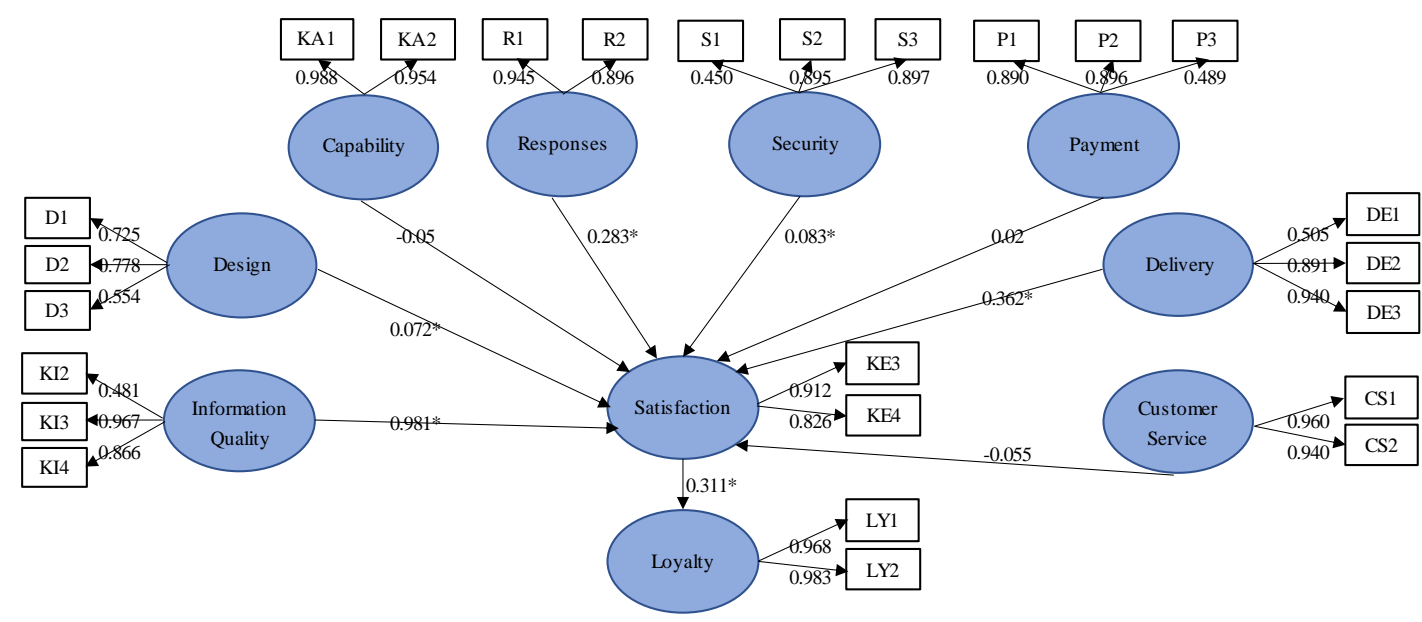

Figure 2. Structural equation modeling of agricultural e-commerce

\section{Validity Indicator}

The validity test of the indicators conducted to ensure that the indicators used were appropriate. The Structural Equation Modeling analysis method provides diverse constraint values i.e., 0.4 (Hanseler, 2009), 0.5 (Hair et al., 2010), and 0.7 (Arikunto, 2010). This study was using Hanseler approach (2009). The use of these criteria based on tests using standard 0.5 (Hair et al., 2010) that found the correlation with the indicator of validity test 1 . There were three declared invalid indicators with a value below 0.5 . The research model without invalid indicators was subsequently reprocessed to obtain better results to solve the problems of study.

The determination test is a test that illustrates the ability of a model described by its constituent variables. The determination test usually uses the R-square output value. In the satisfaction model, it has known that it has a value of 0.96 or 96 percent. This states that the variables in the model can explain 96 percent satisfaction for the users of agricultural e-commerce applications. The loyalty model is known to have a value of 0.92 or 92 percent. The satisfaction variable alone can give a picture of 92 percent and the rest from outside the model.

\section{Hypotheses Testing Research Model}

Hypotheses test used to prove the correlations among variables. In this study, the hypotheses tested have nine significant correlations. The relationship between the variables which declared significant is the relationship between two variables which have an output $\mathrm{P}-\mathrm{Value}$ below 5 percent or 0.05 . The discussion of each relationship is presented in Table 2. 
Factor Affecting User Satisfaction ... (Nusifera, Najib, Kirbrandoko)

\begin{tabular}{lccccc}
\hline \multicolumn{5}{c}{ Table 2. Research Hypotheses Testing } \\
\hline & Hypothesis & & estimate & p-value & Information \\
\hline Information quality & $->$ & Satisfaction & 0981 & $* * *$ & Significant \\
Design & $->$ & Satisfaction & 0072 & 0029 & Significant \\
Capability & $->$ & Satisfaction & -0.05 & 0127 & Not significant \\
Responses & $->$ & Satisfaction & 0283 & $* * *$ & Significant \\
Security & $->$ & Satisfaction & 0083 & 0035 & Significant \\
Payment & $->$ & Satisfaction & $0: 02$ & 0195 & Not significant \\
Delivery & $->$ & Satisfaction & 0362 & $* * *$ & Significant \\
Customer_Service & $->$ & Satisfaction & -0055 & 0062 & Not significant \\
Satisfaction & $->$ & Loyalty & 0311 & $* * *$ & Significant \\
\hline
\end{tabular}

The relationship between the information quality variable on the satisfaction variable is proven to have a positive and significant effect. This condition caused by users consider that most of the developers e-commerce applications have provided products which are easy to understand, the information contained in the application is easy to find and relevant to their needs. These three things are considered to have a role in increasing user satisfaction. It is in line with Ayyash's (2015), where the quality of information greatly affected customer satisfaction.

As a company that sells its goods through application media, the company must be able to present complete and accurate information according to the needs of their customers. Therefore, this will make it easier for consumers in the process of finding and selecting the products they will buy. This can increase customer satisfaction and loyalty. Liu et al. (2008) states, consumers evaluate the information quality with four dimensions, namely accuracy of the information, completeness of information, completeness of information, and relevance of data. Further, The correlation of design variables with satisfaction variables was positive and significant. Applications in online businesses can be described as store displays so that attractive application designs can enhance customer purchasing decisions in line with (Salehi et al., 2012). Chen and $\mathrm{Wu}$ (2017) state that stores must present food photos. Otherwise, consumers will never order food at the store. Consumers will be interested in making purchases based on the recommendations of friends, previous buyers, photos, and reviews from previous consumers.

The correlation of response variables and the satisfaction variable was significant. This finding is due to the performance capabilities of applications that operate well or have no bugs. Kassim and Abdullah (2010) reinforce that responsive applications will be interesting because they will not dissapoint the consumers. The correlation of security and satisfaction was proven to have a significant effect on this condition caused by e-commerce applications' ability to ensure that data from users will be safe. Jin and Park (2006) show a positive impact of security on satisfaction because the data provided and the transactions made guaranteed. Delivery has a significant correlation to satisfaction. Users who bought products from the applications expect that the products delivered on time according to the schedule of the claims. Putra and Octavia (2017) explained that the delivery provided by the company could have a good impact on the company due to the easiness it which is provided. Still, consumers also demand the speed and safety of product delivery so that the effects can significantly increase satisfaction. The satisfaction of the application users has a significant impact on loyalty. The satisfaction that occurred in consumers shaped by the quality of information, design, response, security, and delivery that met users' expectations. Respondent satisfaction is also influenced by the distribution of ordered products, where customers expect certainty of the time and safety of the products they order (Mahmood, 2016).

The correlation between capability and satisfaction was proven insignificant. Respondents who also used e-commerce applications often run out of stock or the unavailability of products sold, so users must have looked elsewhere whether using other agricultural or conventional e-commerce. The payment variable on satisfaction was proven to have no significant effect because users did not issue payment. Application developers have provided various facilities for its users to transact. Customer service has no significant impact on satisfaction. Users have not been able to assess the services provided with certainty because the majority of customers have not felt the service from customer service provided by the developers.

Quick response from sellers or shop owners in e-commerce should be a point of respondent satisfaction because it provides an enjoyable shopping experience. According to Marx and Erasmus (2006), customer service is supposed to add significant and satisfactory value to purchasing experience, increase 
customer satisfaction, and add to the overall perception of service quality with a prospect of customer loyalty. Mohammad et al. (2015) explain that service has a strong influence on customer satisfaction. In ecommerce, it often associates with the ability to respond to every request from its customers.

Overall, the quality of information, design, response, security, and speed of service delivery has a positive and significant impact on the satisfaction of users of agricultural applications. Consumers who want to buy agricultural products online expect the easiness of getting products and shorter time. In addition, the safety of consumers' data and payment processes becomes an important point of consumer satisfaction. According to Oresanya and Oresanya (2016), convenience and time-saving advantages mostly influence their decision to shop online. Although the students had a positive attitude towards online shopping, they were likely to be constrained chiefly by network instability, concern for the safety of their debit/credit cards, and delivered goods looking different from the ones seen online. The social media should be fully utilized for marketing and advertising agricultural products and their web-stores since the majority sourced information from this medium. Prospective online agricultural retailers and marketers should build a reliable and robust e-commerce platform to build consumer trust and loyalty.

In agricultural application users in Indonesia, consumer satisfaction has a positive and significant relationship to consumer loyalty. Consumers who are satisfied with the agricultural products will increase consumer loyalty so that this can increase the likelihood of consumers to buy back the product. According to Vuuren et al. (2012), consumer satisfaction has the highest correlation with consumer loyalty. Consumer loyalty can make consumers purchase retention so that this makes the company get more profits for the business itself and business sustainability in the future.

The study results of the relationship between variables tested in the study produced the implications presented in Table 3. The results showed that customer satisfaction was influenced by the quality of information, design, response, security, and delivery. In developing online-based services (applications) on agricultural e-commerce startups, companies must pay attention to the company's customer data. Loyalty programs could be built using customer data with the same demographic profile. Companies can re-segment customer data to determine target customers who will be exposed to this loyalty program.

Companies must evaluate and develop application content. The quality of information and design affects the satisfaction of agricultural e-commerce users. Companies must pay attention to the content of the appearance of the application both in terms of the quality of the information presented to the design of images, colors, image placement, and grouping of product categories to be sold. Information content and classification of product categories are important keys to make customers come to online stores. To make consumers easier during the product search process, companies can carry out assortments or classify product categories and redesign the appearance of the application to be more user friendly.

Application speed, easiness of operation of the application, and minimal crashes will increase respondents' satisfaction. Hence, if this can be fulfilled, respondents will repurchase on the agricultural ecommerce application. Agricultural e-commerce companies must continue to correct system errors that occur in the field. Improving application performance and minimizing crashes will affect the increasing of customer satisfaction.

The speed of delivery and the suitability of the products sent are important keys to obtaining respondent satisfaction. Satisfied respondents will give a good review of the agricultural e-commerce application. If the company has problems in shipping products, this must be resolved immediately. One of them is by collaborating with a distributor company or freight forwarding service.

According to Nijjer (2020), the results of a survey of the most critical factors that make consumers loyal to a product or service are consumers inspired by the product and price. The first thing to do in creating a customer loyalty program is to build authentic connections with customers and encourage customers to get involved., one of which is by frequently interacting with customers. Companies can invite customers to participate in product reviews and share pictures about the products which they buy.

Customer Relationship Management (CRM) is believed to increase consumer loyalty. Companies can create loyalty programs such as membership programs by giving special customer discounts. In addition, companies can also make give away to customers who want to provide a review of the products they have purchased. The best reviews will be chosen and given attractive prizes. Companies can also bundle products with other categories so that customers try new products that have never been purchased as well as a free shipping program with a minimum purchase.

In agricultural application companies, partners are also an important point for the company. To increase customer satisfaction, companies can process customer purchase data to find out what products are being purchased the most and create special promos for partners whose stores and products fall into this category so that this can attract consumers to make repurchases. 


\section{Conclusions, suggestions and limitations}

Characteristics respondents of agricultural e-commerce users are known to be the majority of women aged 20-30 years. The majority of respondents are getting married, having a good educational background, and work as private employees and civil servants. The agricultural e-commerce applications that respondents often use to shop are Box Vegetables and Happy Fresh. Respondents shop for fruit more often than vegetables with a nominal transaction range of under two hundred thousand rupiah. Before making a purchase in the agricultural e-commerce application, respondents conducted a search for information from consumer purchases on the internet. When the goods arrive, satisfied and also dissatisfied respondents will share their experiences regarding agricultural e-commerce products with other social media users.

Satisfaction of respondents using agricultural e-commerce applications is due to the significant effect of the variables of information quality, design, response, security, and delivery. Meanwhile, the payment, customer service, and capability variables do not significantly affect satisfaction and loyalty. The relationship between the satisfaction variable and loyalty is known to have a significant effect.

The quality of Information, design, response, security, and delivery have greatly affected the satisfaction and loyalty of respondents who use agricultural e-commerce applications. Application service providers must continue to evaluate information content and application design, maintain consumer data security, simplify the process of delivering goods, and pay attention to consumer reviews so that respondents can continue to share good experiences while using the application.

Research data collection was conducted before the Covid-19 pandemic in Indonesia. The characteristics and spending behavior of respondents may change along with changes in the environment. Further research can be carried out by targeting respondents who during the Covid-19 pandemic made online purchases on agricultural e-commerce applications. Further research can be carried out research on customer purchase retention can be carried out to obtain broader information in business development in agricultural e-commerce.

\section{References}

Alwafi, F., \& Magnadi, R.H. (2016). Pengaruh persepsi keamanan, kemudahan bertransaksi, kepercayaan terhadap toko dan pengalaman berbelanja terhadap minat beli secara online pada situs jual beli tokopedia.com. Diponegoro journal of management, 5(2),1-15.

Andarwati, S.R., \& Sankarto, B.S. (2008). Pemenuhan kepuasan penggunaan internet oleh peneliti badan LITBANG pertanian di Bogor. Jurnal Perpustakaan Pertanian, 14(1), 10-17.

Arikunto, S. (2010). Prosedur Penelitian Suatu Pendekatan Praktik. Jakarta, ID: Rineka Cipta.

Ayyash, M. M. (2015). Identifying information quality dimensions that affect customers the satisfaction of e-banking services. Journal of Theoritical and Applied Information Technology, 82(1), 121-130.

Bhaskar, P.P., \& Kumar, P. (2015). E-loyalty and e-satisfaction of e-commerce. International Journal in Management and Social Science, 3(11), 489-498.

Chen, F., \& Wu, J. (2017). Knowing more about people ordering food online. [Thesis]. Jonkoping, SE, Jonkoping University.

Chen, Z., Ling, K.C., Ying, G.X., \& Meng, T.C. (2012). Antecedents of online customer satisfaction in china. International Business Management, 6(2), 168-175.

Das, K., Gryseels, M., Sudhir, P., \& Tan, K.T. (2016.) Unlocking Indonesia's digital opportunity. McKinsey Indonesia

Office. https://www.mckinsey.com/ /media/McKinsey/Locations/Asia/Indonesia/Our\%20Insights/Unlo cking\%20Indonesias\%20digital\%20opportunity/Unlocking_Indonesias_digital_opportunity.ashx

Deloitte. (2014). Deloitte consumer review: the growing of consumers. http://emprenderioja.es/files/recurso/uk-cb-consumer-review-edition-8.pdf

Deloitte. (2017). Deloitte Consumer Insights: Embracing bricks and clicks in Indonesia. https://www2.deloitte.com/content/dam/Deloitte/sg/Documents/consumer-business/sea-cipdeloitte-consumer-insights-embracing-bricks-and-clicks-in-indonesia.pdf

Dharmesti, M.D.D., \& Nugroho, S.S. (2012). The Antecedents of online customer satisfaction and customer loyalty. Journal of Business and Retail Management Research, 7(2), 1-12.

Farag, S., \& Lyons, G. D. (2007). Conceptualizing barriers to travel information use. In the 39th Annual Universities Transport Study Group Conference. Harrogate, UK. Retrieved from http://eprints.uwe.ac.uk/9798/ 
Fatikasari, C.D. (2018). Pengaruh persepsi keamanan, persepsi privacy, dan brand awareness terhadap kepercayaan konsumen online dengan kepuasan sebagai variabel mediasi (studi pada pengguna media sosial instagram di yogyakarta). Jurnal Manajemen Bisnis Indonesia, 2(4), 137-149.

Floh, A., \& Koller, M., Zauner, A. (2013). Taking a deeper look at online reviews: The asymmetric effect of valence intensity on shopping behaviour. Journal of Marketing Management, 29(5-6), 646-670.

Gajic, N., \& Booklaky, M. (2015). Impact of Technical Support on Customer Satisfaction: Case of Automotive Paint. Sage journal, 1(4), 1-19

Hair, J.F., Bush, R.P., \& Ortinau, D.J. (2010). Marketing Reseach Within a Changing Information Environment. New York, NY: McGraw-Hill Companies.

Henseler, J., Ringle, C.M., Sinkovics, R.R. (2009). The Use of Partial Least Squares Path Modeling in International Marketing. New Challenges to International Marketing Advances in International Marketing, 2, 277-319.

Hidayati, N., \& Harimurti, F. (2017). Pengaruh faktor yang memengaruhi kepuasan pengguna e-filling. Riset akutansi dan keuangan, 2(2), 156-164

Humphrey, D.B. (2001). Payment Systems: Principles, Practice, and Improvements. Washington DC, US: The World Bank.

Jin, B., \& Park, J. Y. (2006). The moderating effect of online purchase experience on the evaluation of online store attributes and the subsequent impact on market response outcomes. Advances in consumer research, 33(4), 203-211.

Kassim, N., \& Abdullah, N. A. (2010). The Effect of Perceived Service Quality Dimentions on Customer Satisfaction, Trust and Loyalty in E-commerce Settings: A Cross Cultural Analysis. Asia Paific Journal of Marketing and Logistic, 22(3), 351-371.

Katadata. 2018. Penjualan E-Commerce Indonesia Mencapai US\$ 16 Miliar. https://databoks.katadata.co.id/datapublish/2018/02/12/2022-penjualan-e-commerce-indonesiamencapai-rp-16-miliar.

Khan, A. G. (2016). Electronic commerce: A study on benefits and challenges in an emerging economy. Global Journal of Management and Business Research: B Economics and Commerce, 16(1), 1822. Online ISSN: $2249-4588$

Kim, J., \& Park, J. (2005). A consumer shopping channel extension model: attitude shift toward the online storell. Journal of Fashion Marketing \& Management, 9(1), 106 -121.

Kim, S., \& Stoel, L. (2004). Apparel retailers: Website quality dimensions and satisfaction. Journal of retailing and consumer services, 11(2), 109-117.

Kotler, P. 2010. Manajemen Pemasaran. Jakarta, ID: Erlangga.

Kotler, P., \& Keller, K.L. (2009). Manajemen Pemasaran. Jakarta, ID: Erlangga

Kusuma, A.P., \& Prasetya, K.A. (2017). Perancangan dan implementasi e-commerce untuk penjualan baju online berbasis android. Jurnal Ilmiah Teknik Informatika, 11(1). https://doi.org/10.35457/antivirus.v11i1.194.

Lackermair, G., Kailer, D., \& Kanmaz, K. (2013). Importance of online product reviews from a consumer's perspective. Advance in Economics and Business, 1(1), 1-5.

Liu, X., He, M., Gao, F., \& Xie, P. (2008). An Empirical Study of Online Shopping CustomerSatisfaction in China: A Holistic Perspective. International Journal of Retail \& Distribution Management, 36(11), 919-940. doi:10.1108/09590550810911683.

Lupiyoadi, R.H.A. (2011). Manajemen Pemasaran Jasa. Jakarta, ID: Salemba Empat.

Mahmood, S. M. F. (2016). E-commerce, online shopping, and customer satisfaction: an empirical study on e-commerce system in Dhaka. International Journal of Entrepreneur ship and Development Studies, 4(3), 323-338.

Manoppo, C. A., \& Abdurachman, E. (2009). Analisis atribut pemasaran pada beberapa restoran cepat saji di Jakarta. Journal of Business Strategy and Execution, 2, 63-84.

Mardatilla, R., Kusyanti, A., \& Aryadita, H. (2017). Pengaruh kualitas layanan terhadap kepuasan, kepercayaan dan loyalitas pelanggan pada e-commerce (studi kasus: berrybenka). Jurnal Pengembangan Teknologi Informasi dan Ilmu Komputer, 1(12), 1822-1833.

Marx, N. J. M. M., \& Erasmus, A. C. (2006). An evaluation of the customer service in supermarkets in Proteria East, Tshwane Metropolis, South Africa. Journal of Family Ecology and Consumer Sciences, 43, 56-68.

Moenir, A.S. (2010). Manajemen pelayanan umum di indonesia. Jakarta, ID: Bumi Aksara.

Mohammad, M., Ismail, W. Z. W., \& Salim, N. A. M. A. (2015). E-commerce service quality on customer satisfaction, belief, and loyalty: a proposal. Mediterranean Journal of social Sciences, 6(2), 260268. 
Musfar, T.F., \& Vivi, N. (2012). Pengaruh experiential marketing terhadap customer loyalty pada pelanggan restoran koki sunda di pekanbaru. Jurnal ekonomi, 20(4), 41-49.

Nijjer, R. (2020). Today's e-commerce customer loyalty: designing programs for growth. https://www.mytotalretail.com/article/todays-e-commerce-customer-loyalty-designingprograms-for-growth/

Oresanya AJ, \& Oresanya TJ. 2016. Attitude of students towards online shopping of agricultural products in selected tertiary institutions in Ogun state, Nigeria. Journal of Agricultural Extension. 20(1): 121-131. Http://dx.doi.org/10.4314/jae.v20i1.10

Permani, R. (2020). Reflections on agriculture and its role. https://www.thejakartapost.com/academia/2020/04/21/reflections-on-agriculture-and-itsrole.html

Putra, J. I., \& Octavia, D. (2017). Analysis of factors influencing consumer satisfaction online shopping in the province of java. Jurnal manajemen Indonesia, 17(2), 103 - 111.

Rachman, M., \& Safri, I. (2018). Analisis kualitas pelayanan pada pizza hut sudirman pekanbaru riau. Jurnal valuta, 4(1), 40-56.

Rangkuti, F. (2011). Riset Pemasaran. Jakarta, ID: PT Gramedia Pustaka.

Rasli, S., Khairi, N., Ayathuary, H., \& Sudirman, M. S. (2018). The impact of e-business website quality on customer satisfaction. Journal of Theoretical and Applied Information Technology, 97(2), 102112.

Salehi, M., Mirzaei, H., Aghaei, M., \& Abyari, A. (2012). Dissimilarity of emarketing vs traditional marketing. Conference: 2012 IEDRC Singapore Conferences, 2(1), 384-389.

Semejin, J., Van, R.A.C.R., Van Birgele, M.J.H., \& Streukens, S. (2005). E-services and Offline Fulfillment: How e-Loyalty is Creatd. Managing Service Quality, 15(2), 182-95.

Shanka, V., Smith, A.K., \& Rangaswamy, A. (2003). Customer Satisfaction and Loyalty in Online and Offline Environment. International Journal of Research in Marketing, 20(2), 153-175.

Soemanto, W. (1998). Psikologi Pendidikan. Bandung, ID: Rineka Cipta.

Szymanski, D.M., \& Hise, R.T. (2000). E-Satisfaction: An Initial Examination. Journal of Retailing, 76(3), 309-322.

Teviana, T., Ginting, P., Lubis, A.N., \& Gultom, P. (2017). Antecedents of tourism destination image and customer satisfaction in tourism industry. European research studies journal, 20(3), 435-445.

Tjiptono, G. (2000). Manajemen jasa. Jakarta, ID: Andi Offset.

Tsoukatos, E., \& Rand, G.K. (2006). Path Analysis of Perceived Service Quality, Satisfaction and Loyalty in Greek Insurance. Managing Service Quality, 16(5), 501-19.

Vuuren, T. V., Lombard, M. R., \& Tonder, E. V. (2012). Customer satisfaction, trust, and commitment as predictors of customer loyalty within an optometric practice environment. Southern African Business Review, 16(3), 81-96.

Yashinta, A. (2017). Model Bisnis E-commerce produk pertanian (studi kasus pada PT. Limakilo maju bersama petani). Jurnal Manajemen dan Bisnis, 14(2). 